\title{
Crisis Communications Response among Yemeni Security Sector Institutions: Efficiency and Assessments by Employees
}

\author{
Fuad Mohsen Mohammed Nasr ${ }^{1}$ and Tang Zhen $^{2}$ \\ College of business administrations, Hohai University, Nanjing, China \\ Ifuadchina@yahoo.com, ${ }^{2}$ tangzh@hhu.edu.cn
}

\begin{abstract}
This study examines the role and means of communication in crisis management. It is particularly focused on types, methods, and tools utilized in crisis management in the Yemeni security sector. In this study, 143 employees of security sector operation rooms were surveyed. The responses measure the extent of efficiency of communications during the response phase, as well as indicate the types, methods, and means of contact, and identify obstacles to communication and proposals to overcome these hindrances and activate communication. Preparedness was found to be positively correlated with effective communication from the senior leadership to executive level. The most effective modes of communication occur directly between department heads via oral communication and the dial (wire line, mobile phone, fax, wireless network connections). However, obstacles to effective communication often include a lack of interest in updating the communication devices. The results showed that the lack of communication plays an important factor in the current situation of crisis in security sector. Accordingly, the most important proposals to activate the role of communication in the security crisis management include: fast implementation of the communication process, availability of modern communication devices, and availability of the necessary tools for communication during crisis management.
\end{abstract}

Keywords: Crisis Management, Effective Communication, Security Institutions, Yemen

\section{Introduction}

In the contemporary era, the challenges confronting human societies in maintaining control over their safety are very serious. Developed countries have designed mutually dependent crisis networks in order to control security crises. However, the computing of security information regarding crisis intervention and quick response is essential to maintaining security in daily activities, especially during these times of increased instances of terrorism and societal challenges [1]. During a crisis, change occurs at such a rapid pace, which can have profound consequences for individuals and society. In order to prevent these consequences, it is essential to create a plan for crisis intervention, which involves prompt response, effective communication, and a unified working environment within the security sector [2]. Timothy Coombs, emphasizes that the best place to start crisis management effort is to define critical concepts [3]. He emphasizes that numerous volumes have been written about crisis management by both practitioners and researchers from many different disciplines, making it a challenge to synthesize the information into one comprehensive plan. Utilizing modern technology in coordination with the exchange of information among relevant agencies leads to the effective confrontation of risks, disasters, crises, and mitigation [3]. It is also important to encourage and facilitate communication between various agencies in the security sector. Therefore, various communication technologies, such as online databases, online networks, and email could greatly improve crisis management strategies. Additionally, employees should be trained 
and responsible to update and maintain these communication tools, in order to achieve maximum efficiency and foster communication between agencies [4].

Today, communication tools play an important role in various aspects of life, especially in security matters. Both predictable and unforeseen events require prompt intervention, which is aided by the implementation of Information and Communication Technologies (ICT). Therefore, workers in the various security sectors must be alert and able to utilize various forms of ICT, in order to effectively manage a crisis [5]. In all countries or societies, it is a government responsibility to put a system in place to deal with complex operations and the management of crises and disasters. Coordination, command, and control are essential elements of a successful system, which monitors crisis and disaster management tasks [6].

Therefore, this study assesses the effectiveness of the role of communications in the Yemeni security sector. Moreover, it investigates the most common types, methods, and tools of communications utilized in crisis management in Yemen. Finally, this study identifies the obstacles that hinder the effectiveness of communication, as well as proposes plans to activate the role of communications in security crisis management. Four security sectors in Yemen, which have a prominent role in dealing with disasters and crises, were considered in this study to examine the first line of defense in crisis management—command and control operating rooms.

\subsection{Research Questions and Hypotheses}

This study explores the answers to the following research objectives:

RO1: What are the types, methods, and tools of communication used to respond to crises and disasters in the Yemen security sector?

RO2: What are the major factors that hinder effective communication during crisis management?

RO3: What are the solutions to these communication obstacles?

The following hypotheses were designed based on the answers to the above mentioned questions:

\section{H1: No relation between:}

1: No relationship (effect) statistically significant at the (0.05) level between the types, methods, and means of communications used and crisis management in operating rooms of security institutions.

2: No relationship (effect) statistically significant at the (0.05) level among the factors that hinder effective communication and crisis management in operating rooms of security institutions.

3: No relationship (effect) statistically significant at the (0.05) level between the solutions proposed to avoid obstacles in effective communication and crisis management in operating rooms of security institutions.

H2: No significant relationship between the study variables and effectiveness of communication attributable to demographic data.

\subsection{Research Model}

In this study, the security sectors (police, civil defense, command and control, police hospitals) in Sana'a City, Yemen's capital were observed. These sectors represent the first line of defense in the face of crises and disasters. The participants in this study include the staff in the operating rooms of these sectors. Additionally, the study focuses on the efficiency of communication in crisis management situations by examining the efficacy of 
intercommunication between the various security sectors during the crisis, as well as administrative procedures following the crisis. Finally, this study identifies factors that hinder effective communication within security institutions, and measurements which have been applied to avoid obstacles and know the impact of demographic factors on the effectiveness of communication uses as shown in Figure 1.

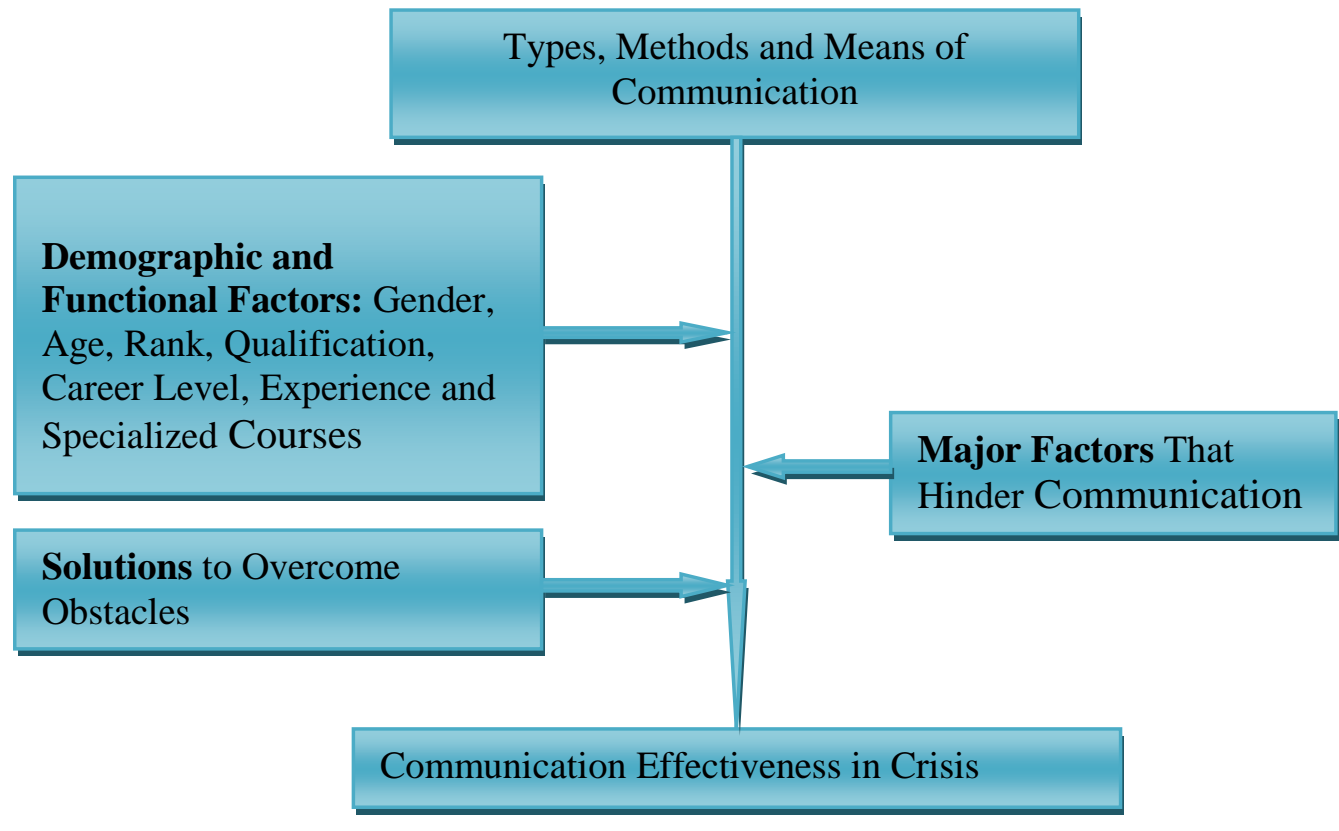

Figure 1.The Research Conceptual Model

\section{Literature Review}

The implementation of communication tools is a crucial element in ensuring prompt and efficient response during crisis situations. This section outlines the background of crisis management and focuses on communication, especially in security crises occurring in different areas of the world.

\subsection{Crisis Management}

Literature surrounding the topic of crisis management defines a crisis as a specific, unexpected, and non-routine event, or series of events, with potentially serious ramifications that would result in the profound change of an organization. It is important to note that a crisis differs from an emergency or problem in that it is serious enough to cause drastic change. Therefore, the very existence of the organization could be in danger. In turn, crisis management is the application of strategies designed to help an organization deal with these unexpected events. These strategies for preventing and managing crises may only be successful if a coherent communication strategy is in place. Suleiman, of Saudi Arabia, reports that crisis management requires advanced communication systems, which utilize the latest programs and technology, in order to quickly gain control over the situation [7]. In addition, Hilal states that satellite is a necessary communication tool because of its speed and efficiency in the transfer of information to any location [8].

The efficient management of crises is an interactive process, and requires an integrated structure of public relations combined with effective communication. In order to prevent undesired events from occurring, or to diminish the risk of crisis, it is necessary to take precautions before a crisis is even apparent. Pre-crisis plans must be determined by a crisis management team. Crisis management teams are typically comprised of employees 
in public relations, operations, security, legal, human resources and finance sectors. According to Coombs includes social media managers as important members of these teams [9]. The team members are responsible for assigning tasks and responsibilities during a crisis [10]. In addition, crisis management teams should prepare a critical plan to serve as a guide for what should be done in response to a crisis. The plan should include key contact information and forms necessary to document the crisis response; however, this crisis management plan is not a step-by-step guide to how to manage a crisis[9], notes how a plan saves time during a crisis by pre-collecting important information, preassigning tasks, and serving as a reference source.

Crisis response is defined as the actions management takes after the crisis hits. Public relations play a critical role in the crisis response by helping to develop the messages that are sent to various groups. A great deal of research has examined crisis response, which is utilized together with practitioner experience to create a clear set of guidelines on how to respond when crisis strikes. The initial crisis response guidelines focus on three points: (1) be quick, (2) be accurate and (3) be consistent[3]. Therefore, security crisis management is both a science and an art, because it requires a scientific approach as well as creativity to overcome a security crisis.

\subsection{Security Crisis}

Security crisis occurs when social security is threatened and the united efforts of various security agencies is required in order to prevent collapse. Security crises often take the form of a natural disaster or terrorist attack, leading to loss of life or large scale property damage. Many security crises are characterized by violence, which requires the timely intervention of security services at the time and place of the confrontation. In the sudden onset of a security crisis, prompt response is essential, because a delay in response leaves the public vulnerable to further danger. According to Al Shaalan these violent security crises often involve loss of life and property, and failure to properly respond to these events causes citizens to feel a lack of security [11].

However, crisis management comes with challenges and risks. Mismanagement of the security sector in the Yemeni government led to a crisis which spanned the majority of the last decade. As a result, conflicts were exacerbated and tensions led to violent clashes, large displacements of the population and significant casualties, in addition to the flow of many refugees to Yemen from neighboring African countries. Therefore, security crisis management is scientific and artful at the same time because it relies on scientific rules and methods, and requires the application of a range of abilities, skills, and creativity in order to address the security crisis

\subsection{Crisis Communications}

Communication is a diverse process. According to [12], it is the process of exchanging information and ideas using a common system of signs, symbols, or behaviors. Communication plays an important role in the containment of crises, especially security crises.

Often, the cause of security disasters is a lack of effective communication. Throughout world history, there have been numerous events in which crisis prevention and response failed due to failures in the communication process. For example, the US Navy was soundly defeated at Pearl Harborin one of the greatest military disasters in American history. American leaders at Pearl Harbor noticed the approach of aircrafts in the area, but they did not inform the General Command stationed in the Hawaiian Islands, thus stopping the communication process and leading to disaster [13].

In 1454, Gutenberg invented moveable type and printed the bible, thus beginning the print communications revolution. Printing books become a sensation as printing presses 
became widespread across Europe, marking the departure from spoken word to print. The printing press added permanence to words phrases, and speeches.

The Communication/Public Information Response Team is one of several Crisis Response Teams. The team is responsible for providing information to all affected parties in a crisis, including the public, concerned authorities, and the media.

Team Responsibilities:

- Crafting and disseminating announcements, warnings, information and updates using the appropriate communication tools for the situation

- Responding to inquiries from media and the general public

- Arranging news conferences as needed

- Monitoring media/public reaction and sharing information with other Crisis Management Team members as needed

- Directing other Communication/Public Information, Response Team members to assist as needed

The concept of crisis communications involves various communicative roles which act during various stages of a crisis [11]. This study involves the transfer and exchange of information between the operational staff of command and control rooms and the decision makers, in order to make vital decisions to end the crisis. Transfer of information to the public is also important during a crisis. Specifically, Hallahan pointed out that contemporary models of public relations are based on two-way communication rather one-way transmission models of communication, which recognize and engage audiences in an inclusive 'win-win' process [14]. There are a number of important standards in dealing with the communication of the details of a crisis. These standards include: [7].

1-Crisis management teams should respond promptly and efficiently at all levels, including internal and external levels of command, in control chambers, and at the location of the crisis.

2-Ensure that cooperation with the media does not impact the efficacy of crisis management.

3-Assign an official spokesperson to communicate directly with the media, this person takes on the responsibility of relaying all necessary and appropriate information about the crisis, without impeding the success of the management team.

\section{Methods}

The questionnaire given to the study population was designed based on a review of the presented literature. This research acquired the necessary insights to formulate the questions that reflected the overall study purpose.

This study was conducted under the supervision of senior management institutions and in collaboration with other relevant departments. Those included in the study are employees of operation room's staff in the security services (i.e., Police, Civil Defense, Police Hospitals, and Command and Control). One hundred and seventy-four questionnaires were distributed and one hundred and forty-three were recovered to complete this study. The questionnaires are divided into six sections (i.e., A, B, C, D, E, and $\mathrm{F}$ ) with a total of thirty-nine questions, in addition to demographic data.

Section (A) focuses on demographic details of the respondent. Section (B) addresses types of communications that are used in security crisis management. Section (C) addresses methods of communication the administration uses in times of security crises. Section (D) addresses the means of communication used in security crisis management. Section (E) investigates factors that hinder the effectiveness of the communication 
process in security crisis management. Lastly, section $(\mathrm{F})$ proposes to evaluate the role of communications in security crisis management situations.

The questionnaire was designed based on the Likert Scale, which employs a five-point rating scale in order to determine the subject's level of agreement to a proposed topic or question. This scale ranges from 'strongly disagree' (choice one) to 'strongly agree' (choice five). These five-point rating scales were distributed to represent a balanced scale between the extreme positive (five) and the extremely negative (one), and based on the responses of the study, patterns in the population's tendencies can be determined [15], [16]. Data for this study was collected in 2015.

The questionnaire variables were processed in accordance with the literature. Most of the survey items were based on research conducted by [17], [7] ,[18], although some were modeled based on a previous qualitative study. The questionnaire was examined and approved by academics to ensure its viability. Accordingly, some suggested items were added to improve the questionnaire structure.

The data was collected, analyzed, and presented in table format. Based on the results, study questions and hypotheses were stated and the responses to objectives were discussed. Then, analysis related to the research hypothesis was conducted using Statistical Package for the Social Sciences (SPSS) software. Mean, standard deviation, and chi-square tests is used to find out the frequency of answers to the questions of the study items. In addition, one way analysis of variance - ANOVA is used to find out whether there were statistically significant differences between three or more sets of demographic profiles.

\subsection{Research Sample}

The research samples consisted of 143 usable surveys (out of 174), representing a response rate of $82 \%$. Due to the nature of the social structure in Yemen, the surveyed populations are predominately male $(93.7 \%)$, with female participation at $6.3 \%$.

Table 1. The Distribution of Respondents

\begin{tabular}{|l|l|l|l|}
\hline \multirow{5}{*}{ Gender } & Male & 134 & 93.7 \\
\cline { 2 - 4 } & Female & 9 & 6.3 \\
\cline { 2 - 4 } & Total & 143 & 100 \\
\hline \multirow{5}{*}{ Anstitutions } & police & 35 & 24.5 \\
\cline { 2 - 4 } & Police Hospitals & 31 & 21.7 \\
\cline { 2 - 4 } & Civil Defense & 39 & 27.3 \\
\cline { 2 - 4 } & Command and Control & 38 & 26.6 \\
\cline { 2 - 4 } & Total & 143 & 100 \\
\hline \multirow{5}{*}{ Qualification } & $30 \geq$ & 64 & 44.8 \\
\cline { 2 - 4 } & $31-40$ & 59 & 41.3 \\
\cline { 2 - 4 } & $40-50$ & 18 & 12.6 \\
\cline { 2 - 4 } & $50 \leq$ & 2 & 1.4 \\
\cline { 2 - 4 } & Total & 143 & 100 \\
\hline \multirow{5}{*}{ Career Level } & High School or less & 22 & 15.4 \\
\cline { 2 - 4 } & Diploma & 21 & 14.7 \\
\cline { 2 - 4 } & Bachelor & 82 & 57.3 \\
\cline { 2 - 4 } & Postgraduate & 18 & 12.6 \\
\cline { 2 - 4 } & Total & 143 & 100 \\
\hline & Less than Head of Section & 51 & 35.7 \\
\cline { 2 - 4 } & Head of Section & 26 & 18.2 \\
\cline { 2 - 4 } & Management Director & 1 & 0.7 \\
\cline { 2 - 4 } & General manager & \\
\hline
\end{tabular}




\begin{tabular}{|c|c|c|c|}
\hline & Other & 28 & 19.6 \\
\hline & Total & 143 & 100 \\
\hline \multirow[t]{5}{*}{ Experience } & $1-5$ years & 40 & 28 \\
\hline & $6-10$ years & 27 & 18.9 \\
\hline & 11-15 years old & 33 & 23.1 \\
\hline & More than 15 & 43 & 30.1 \\
\hline & Total & 143 & 100 \\
\hline \multirow{5}{*}{$\begin{array}{l}\text { Courses of } \text { Crisis } \\
\text { Management }\end{array}$} & None & 90 & 62.9 \\
\hline & $1-3$ courses & 41 & 28.7 \\
\hline & 4-6 courses & 11 & 7.7 \\
\hline & More than 7 & 1 & 0.7 \\
\hline & Total & 143 & 100 \\
\hline \multirow{5}{*}{$\begin{array}{l}\text { Courses in Information } \\
\text { Technology }\end{array}$} & None & 47 & 32.9 \\
\hline & $1-3$ courses & 49 & 34.3 \\
\hline & 4-6 courses & 37 & 25.9 \\
\hline & More than 7 & 10 & 7 \\
\hline & Total & 143 & 100 \\
\hline \multirow{3}{*}{$\begin{array}{l}\text { Forums in } \\
\text { Management }\end{array}$} & Yes & 55 & 38.5 \\
\hline & No & 88 & 61.5 \\
\hline & Total & 143 & 100 \\
\hline \multirow{3}{*}{$\begin{array}{l}\text { Forums in Information } \\
\text { Technology }\end{array}$} & Yes & 47 & 32.9 \\
\hline & No & 96 & 67.1 \\
\hline & Total & 143 & 100 \\
\hline \multirow[t]{4}{*}{ System of Department } & Manual system & 28 & 19.6 \\
\hline & System depends on the computer & 16 & 11.2 \\
\hline & Manual system and computer together & 99 & 69.2 \\
\hline & Total & 143 & 100 \\
\hline
\end{tabular}

\section{Results}

\subsection{Answer the Research Questions and First Hypothesis}

4.1.1. From the viewpoint of security sector employees in Yemen's capital, Sana'a, what types of connections are used during security crisis management?

This section identifies the most important types of connection utilized in security crisis management. Six items were used to measure system quality construct on a five-point Likert scale, ranging from "never" to "always". Table 2 shows the descriptive statistics (means, standard deviations and chi-square) of the items measuring this construct. 


\section{Table 2. Mean, Standard Deviation, Chi-Square, and Sig of Communications} Types

\begin{tabular}{|c|c|c|c|c|c|c|}
\hline $\mathbf{N}$ & Communications types & $\mathbf{M}$ & SD & $\mathrm{CS}$ & Sig & Rank \\
\hline 1 & $\begin{array}{l}\text { Contact through joint command (Chamber of } \\
\text { joint operations) }\end{array}$ & 3.57 & 1.172 & $31.790 \mathrm{a}$ & $0.000^{*}$ & 3 \\
\hline 2 & $\begin{array}{l}\text { Staffs direct communication with senior } \\
\text { security management. }\end{array}$ & $\begin{array}{l}3.4 \\
1\end{array}$ & 1.146 & $29.902 \mathrm{a}$ & $0.000^{*}$ & 5 \\
\hline 3 & $\begin{array}{l}\text { Informal communication with the } \\
\text { management for fast information transfer }\end{array}$ & $\begin{array}{l}3.4 \\
0\end{array}$ & 1.145 & $29.413 a$ & $0.000^{*}$ & 6 \\
\hline 4 & $\begin{array}{l}\text { Informal contacts to clarify operational side } \\
\text { are preferred. }\end{array}$ & $\begin{array}{l}3.5 \\
2\end{array}$ & 1.162 & $31.790 \mathrm{a}$ & $0.000^{*}$ & 4 \\
\hline 5 & $\begin{array}{l}\text { There more (Widespread) direct contacts } \\
\text { among the administration's managers or } \\
\text { sections for the exchange of information in } \\
\text { order to fast work completion. }\end{array}$ & $\begin{array}{l}3.8 \\
3\end{array}$ & 1.070 & $60.951 \mathrm{a}$ & $0.000^{*}$ & 2 \\
\hline 6 & $\begin{array}{l}\text { Communication mode prevails from the } \\
\text { senior leadership to executive levels }\end{array}$ & $\begin{array}{l}3.8 \\
5\end{array}$ & 1.027 & $67.385 \mathrm{a}$ & $0.000^{*}$ & 1 \\
\hline
\end{tabular}

$* \mathrm{P}<.05$.

Table 2 indicates the following: These findings show that all values of the Chi-square found statistically significant differences in the test results; it was less than or equal to 0.05 , meaning there are differences in the trends of study sample. In addition, all of the arithmetic means of the values of statements included in this item ranged between (3.353.40).

According to the study, as shown in Table 2, the most common connection types in security crisis management are listed below in descending order:

1-“Communication mode prevails from the senior leadership to executive levels during the crisis management" is ranked first based on degree of agreement, with a mean value of (3.85) and standard deviation of (1.027). The statement refers to the transparency and speed of response to the crisis, as well as communication with decision makers in order to organize the process.

2-"There are more (Widespread) direct contacts among the administration's managers or sections for the exchange of information in order for fast work completion" is ranked second based on degree of agreement, with a mean value of (3.83) and standard deviation of (1.070). This result is consistent with a study[7] Al Hamidi conducted with security service operations workers in Saudi Arabia. These workers also indicated the importance of direct contacts and sharing information between managers, chairpersons, and other departments, during a crisis.

3-“Contact among security institutions through joint command (Rooms of joint operations) in times of crisis" is ranked third based on degree of agreement, with a mean value of (3.57) and standard deviation of (1.172).

4- "Informal contacts during the security crisis to clarify operational side are preferred" is ranked fourth based on degree of agreement, with a mean value of (3.52) and standard deviation of (1.162).

5-"Staff contact with the leaders of security managements directly" is ranked fifth based on degree of agreement, with a mean value of (3.41) and standard deviation of (1.146). 
6- "Informal contact of leadership is encouraged during crisis management for purpose of quick transfer of information" is ranked sixth based on degree of agreement, with a mean value of (3.40) and standard deviation of (1.145).

4.1.2. From the viewpoint of security institution employees in Sana'a, what methods of connection are used during security crisis management? This section will identify the most important methods of connection used in security crisis management.

\section{Table 3. Mean, Standard Deviation, Chi-Square, and Sig of Communications Methods}

\begin{tabular}{|c|l|c|c|c|c|c|}
\hline $\mathbf{N}$ & \multicolumn{1}{|c|}{ Communications Methods } & M & SD & CS & Sig & Rank \\
\hline 1 & $\begin{array}{l}\text { Dependence on the written commands in } \\
\text { communications. }\end{array}$ & 3.43 & 1.172 & $24.308 \mathrm{a}$ & $0.000^{*}$ & 3 \\
\hline 2 & $\begin{array}{l}\text { Using written commands through electronic devices. } \\
3\end{array}$ & 2.6 & 1.14 & $28.573 \mathrm{a}$ & $0.000^{*}$ & 6 \\
\hline 4 & Reliance on the oral direct personal contact. & 4.03 & 0.967 & $90.252 \mathrm{a}$ & $0.000^{*}$ & 2 \\
\hline 5 & Using the oral communication through the devices & 4.11 & 0.935 & $99.203 \mathrm{a}$ & $0.000^{*}$ & 1 \\
\hline 6 & $\begin{array}{l}\text { Reliance on visual communications (direct). } \\
\text { communications extensively. }\end{array}$ & 2.83 & 1.332 & $12.070 \mathrm{a}$ & $0.017 *$ & 5 \\
\hline
\end{tabular}

$* \mathrm{P}<.05$.

Table 3 illustrates the following: All values of Chi-square show statistically significant differences, as the test results are less than or equal to 0.05 , meaning there are differences in trends within the study sample. In addition, all arithmetic means of the values of statements that included in this item ranged between (4.11-2.60).

According to the study results, as shown in Table 3, the most common methods of communication during a crisis are listed below in descending order:

1-“Oral communication via electronic devices" is ranked first, based on degree of agreement, with a mean value of (4.11) and standard deviation of (0.935).

2-"Direct oral communication" is ranked second, based on degree of agreement, with a mean value of (4.03) and standard deviation of (0.967).

3-"Written commands" is ranked third, based on degree of agreement, with a mean value of (3.43) and standard deviation of (1.172).

4-"Modern electronic communications" is ranked fourth, based on degree of agreement, with a mean value of (2.94) and standard deviation of (1.212).

5-"Direct visual communications" is ranked fifth, based on degree of agreement, with a mean value of (2.83) and standard deviation of (1.332).

6-"Written commands via electronic devices" is ranked sixth, based on degree of agreement, with a mean value of (2.60) and standard deviation of (1.140).

4.1.3. From the viewpoint of security institution employees in Sana'a, what means of communication are used during security crisis management?

This part will identify the most important means of communication utilized in security crisis management. 
Table 4. Mean, Standard Deviation, and Chi-Square of Means

\begin{tabular}{|c|l|c|c|c|c|c|}
\hline $\mathbf{N}$ & \multicolumn{1}{|c|}{ Communications Means } & $\mathbf{M}$ & $\mathbf{S D}$ & $\mathbf{C S}$ & Sig & Rank \\
\hline 1 & mobile phone & 4.52 & 0.659 & $128.524^{\mathrm{b}}$ & $0.000^{*}$ & 1 \\
\hline 2 & Fax (plain or encrypted) & 3.82 & 0.997 & $98.923^{\mathrm{a}}$ & $0.000^{*}$ & 2 \\
\hline 3 & wireless communication devices private & 3.78 & 1.234 & $60.252^{\mathrm{a}}$ & $0.000^{*}$ & 3 \\
\hline 4 & $\begin{array}{l}\text { Letters and telegrams are written } \\
\text { (administrative contact) }\end{array}$ & 3.71 & 1.004 & $65.077^{\mathrm{a}}$ & $0.000^{*}$ & 4 \\
\hline 5 & $\begin{array}{l}\text { Personal interviews, meetings or } \\
\text { committees }\end{array}$ & 3.64 & 1.045 & $45.636^{\mathrm{a}}$ & $0.000^{*}$ & 5 \\
\hline 6 & SMS (short messaging) & 3.36 & 1.031 & $46.755^{\mathrm{a}}$ & $0.000^{*}$ & 6 \\
\hline 7 & Intranet & 3.10 & 1.235 & $21.720^{\mathrm{a}}$ & $0.000^{*}$ & 7 \\
\hline 8 & Internet & 2.73 & 1.332 & $7.175^{\mathrm{a}}$ & 0.127 & 8 \\
\hline 9 & E-mail & 2.37 & 1.314 & $32.140^{\mathrm{a}}$ & $0.000^{*}$ & 9 \\
\hline 10 & Chatting & 2.27 & 1.108 & $42.000^{\mathrm{a}}$ & $0.000^{*}$ & 10 \\
\hline 11 & Satellites & 2.06 & 1.191 & $75.287^{\mathrm{a}}$ & $0.000^{*}$ & 12 \\
\hline 12 & MMS (multimedia messages) & 1.257 & $60.252^{\mathrm{a}}$ & $0.000^{*}$ & 11 \\
\hline
\end{tabular}

$* \mathrm{P}<.05$.

a. 0 cells $(0.0 \%)$ have expected frequencies less than 5. The minimum expected cell frequency is 28.6.

b. 0 cells $(0.0 \%)$ have expected frequencies less than 5 . The minimum expected cell frequency is 35.8 .

Table 4 illustrates the following: These findings show that all values of the Chi-square are statistically significant, as differences in the test results are less than or equal to 0.05 , meaning there are differences in trends within the study sample. The first statement is the only exception, in which there is no statistically significant difference, as its value is (0.127). In addition, all arithmetic means of the values of statements included in this item ranged between(2.06-4.52).According to the study results, as shown in Table 4, the most common means of communication during a crisis are listed below in descending order:

1-“The dial (wire line, mobile phone)" is ranked first, based on degree of agreement, with a mean value of (4.52) and standard deviation of (0.659).

2-"Contact Fax (plain or encrypted)" is ranked second, based on degree of agreement, with a mean value of (3.82) and standard deviation of (0.997).

3-"Private wireless network communication (handheld devices and wireless)" is ranked third, based on degree of agreement, with a mean value of (3.78) and standard deviation of (1.234). 
4-"The use of written letters and telegrams (administrative contact)"is ranked fourth, based on degree of agreement, with a mean value of (3.71) and standard deviation of (1.004).

5-"Personal interviews, meetings or a committee" is ranked fifth, based on degree of agreement, with a mean value of (3.64) and standard deviation of (1.045).

6-"SMS via mobile phone (text messaging)" is ranked sixth, based on the degree of agreement, with a mean value of (3.36) and standard deviation of (1.031).

7-"Local communications (network Intranet)" is ranked seventh, based on degree of agreement, with a mean value of (3.10) and standard deviation of (1.235).

8- "World wide web (internet)" is ranked eighth, based on degree of agreement, with a mean value of (2.73) and standard deviation of (1.332).

9-“E-mail" is ranked ninth, based on degree of agreement, with a mean value of (2.37) and standard deviation of (1.314).

10-“Chatting (conversation programs)" is ranked tenth, based on degree of agreement, with a mean value of (2.27) and standard deviation of (1.108).

11-"Communications network reliant upon satellites for communication" is ranked eleventh, based on degree of agreement, with a mean value of (2.13) and standard deviation of (1.257).

12- "MMS via mobile phone (multimedia messages)" is ranked twelfth, based on degree of agreement, with a mean value of (2.06) and standard deviation of (1.191).

4.1.4. From the viewpoint of security institution employees in Sana'a, what are the factors that hinder the effectiveness of the communication process in crisis management?

This part identifies the most important factors that hinder the effectiveness of the communication process in crisis management.

Table 5. Mean, Standard Deviation, and Chi-Square of Obstacles

\begin{tabular}{|l|l|r|r|c|c|c|}
\hline $\mathrm{N}$ & \multicolumn{1}{|c|}{ Obstacle } & M & \multicolumn{1}{c|}{ SD } & \multicolumn{1}{c|}{ CS } & Sig & Rank \\
\hline 1 & $\begin{array}{l}\text { Lack of clarity in the rules and } \\
\text { regulations }\end{array}$ & 3.84 & .962 & $26.930^{\mathrm{a}}$ & $0.000^{*}$ & 5 \\
\hline 2 & Contrariety in competencies & 3.58 & 1.024 & $26.930^{\mathrm{a}}$ & $0.000^{*}$ & 7 \\
\hline 3 & Duplication of the leadership & 3.65 & .816 & $50.594^{\mathrm{a}}$ & $0.000^{*}$ & 6 \\
\hline 4 & Lack of requirements & 4.24 & .839 & $50.594^{\mathrm{a}}$ & $0.000^{*}$ & 1 \\
\hline 5 & $\begin{array}{l}\text { Not updating the } \\
\text { communication devices }\end{array}$ & 4.15 & .816 & $53.224^{\mathrm{a}}$ & $0.000^{*}$ & 2 \\
\hline 6 & $\begin{array}{l}\text { Lack of vocational training to } \\
\text { staff }\end{array}$ & 4.10 & .974 & $95.566^{\mathrm{b}}$ & $0.000^{*}$ & 3 \\
\hline 7 & $\begin{array}{l}\text { Weakness in communication } \\
\text { skills }\end{array}$ & 3.92 & .889 & $95.566^{\mathrm{b}}$ & $0.000^{*}$ & 4 \\
\hline
\end{tabular}

$* \mathrm{P}<.05$.

a. 0 cells $(0.0 \%)$ have expected frequencies less than 5 . The minimum expected cell frequency is 35.8 .

b. 0 cells $(0.0 \%)$ have expected frequencies less than 5. The minimum expected cell frequency is 28.6.

Table 5 illustrates the following: These findings show that all values of the Chi-square are statistically significant, as differences in the test results are less than or equal to 0.05 , meaning there are differences in trends within the study sample. In addition, all the arithmetic means of the values of statements included in this item ranged between (4.24$3.58)$. 
According to the study results, as shown in Table 5, the most common factors hindering effective communication during a crisis are listed below in descending order:

1-"Lack of the necessary requirements to communicate during the crisis" is ranked first, based on degree of agreement with a mean value of (4.24) and standard deviation of (0.839).

2-"Lack of interest in updating the communication devices used in crisis communication" is ranked second, based on degree of agreement, with a mean value of (4.15) and standard deviation of (0.816).

3-"Lack of vocational training to staff in security communication on effective use of communication tools" is ranked third, based on degree of agreement, with a mean value of (4.10) and standard deviation of (0.974).

4-"Weakness in basic communication skills of employees" is ranked fourth, based on degree of agreement, with a mean value of (3.92) and standard deviation of (0.889).

5-"Lack of clarity in the rules and regulations for the communication process during a crisis" is ranked fifth, based on degree of agreement, with a mean value of (3.84) and standard deviation of (0.962).

6-"Duplication of the leadership during the crisis communication management" is ranked sixth, based on degree of agreement, with a mean value of (3.65) and standard deviation of $(0.816)$.

7-"Contrariety in competencies among the implementers of the communication plan" is ranked seventh, based on degree of agreement, with a mean value of (3.58) and standard deviation of (1.024).

4.1.5. From the viewpoint of security institution employees in Sana'a, what are the main proposals to activate the role of communications in security crisis management?

This part will identify the most important proposals to activate the role of communications in security crisis management.

Table 6. Mean, Standard Deviation, and Chi-Square of Proposals

\begin{tabular}{|c|c|c|c|c|c|c|}
\hline $\mathbf{N}$ & Proposals & M & SD & CS & Sig & Rank \\
\hline 1 & Clarity of the rules and regulations & 4.49 & .812 & $202.979^{a}$ & $0.000 *$ & 6 \\
\hline 2 & $\begin{array}{l}\text { Availability of modern communication } \\
\text { devices }\end{array}$ & 4.66 & .662 & $188.385^{\mathrm{b}}$ & $0.000 *$ & 2 \\
\hline 3 & Lack of contrariety in specializations & 4.29 & .863 & $138.364^{\mathrm{a}}$ & $0.000 *$ & 7 \\
\hline 4 & $\begin{array}{l}\text { Fast implementation of the communication } \\
\text { process }\end{array}$ & 4.68 & .564 & $187.154^{\mathrm{b}}$ & $0.000 *$ & 1 \\
\hline 5 & $\begin{array}{l}\text { Availability of the necessary requirements } \\
\text { for communication }\end{array}$ & 4.62 & .554 & $83.510^{c}$ & $0.000 *$ & 3 \\
\hline 6 & $\begin{array}{l}\text { Need to a secure and encrypted } \\
\text { communication system }\end{array}$ & 4.56 & .667 & $143.741^{b}$ & $0.000 *$ & 4 \\
\hline 7 & Usage of visual communication a lot & 3.71 & 1.14 & $39.622^{\mathrm{a}}$ & $0.000^{*}$ & 8 \\
\hline 8 & $\begin{array}{l}\text { Use of modern electronic communications } \\
\text { extensively }\end{array}$ & 4.50 & .711 & $123.042^{\mathrm{b}}$ & $0.000^{*}$ & 5 \\
\hline
\end{tabular}

$* \mathrm{P}<.05$

a. 0 cells $(0.0 \%)$ have expected frequencies less than 5. The minimum expected cell frequency is 28.6.

b. 0 cells $(0.0 \%)$ have expected frequencies less than 5 . The minimum expected cell frequency is 35.8 .

c. 0 cells $(0.0 \%)$ have expected frequencies less than 5 . The minimum expected cell frequency is 47.7. 
Table 6 illustrates the following: These findings show that all values of the Chi-square are statistically significant, as differences in the test results are less than or equal to 0.05 , meaning there are differences in trends within the study sample. In addition, all arithmetic means of the values of statements included in this item ranged between (4.68-3.71).

According to the study results, as shown in Table 6, the most important proposals to activate the role of communication in security crisis management are listed below in descending order:

1-"Fast implementation of the communication process, because it is a decisive factor in confronting the security crisis" is ranked first, based on degree of agreement, with a mean value of (4.68) and standard deviation of (0.564).

2-“Availability of modern communication devices is an important factor improving the status of communication during the crisis" is ranked second, based on degree of agreement, with a mean value of (4.66) and standard deviation of (0.662).

3-"The availability of the necessary requirements for communication during crisis management" is ranked third, based on degree of agreement, with a mean value of (4.62) and standard deviation of (0.554).

4-"The need to a secure an encrypted communication system to foster the confidentiality of information" is ranked fourth, based on degree of agreement, with a mean value of (4.56) and standard deviation of (0.667).

5-"Use of modern electronic communications extensively in communications crisis" is ranked fifth, based on degree of agreement, with a mean value of (4.50) and standard deviation of (0.711).

6-"Clarity of rules and governing regulations during work in security crises" is ranked sixth, based on degree of agreement, with a mean value of (4.49) and standard deviation of $(0.812)$.

7-"Lack of contrariety in specializations among the implementers of communication plan" is ranked seventh, based on degree of agreement, with a mean value of (4.29) and standard deviation of (0.863).

8-"Usage of extensive visual communication during crisis management" is ranked eighth, based on degree of agreement, with a mean value of (3.71) and standard deviation of (1.143).

4.2. Second Hypothesis: Survey results indicated some statistically significant differences within the study population, among various responses to the questionnaire. In this study, the One Way ANOVA test was utilized, in order to determine whether demographic data had an impact on the survey results.

Table 7. The Effect of the Demographic Profile on Items

\begin{tabular}{|l|c|c|c|c|c|c|}
\hline Demographic Profile & analysis & Type & Method & Means & Obstacles & solutions \\
\hline \multirow{2}{*}{ Institutions } & Sig. & 0.070 & 0.083 & 0.912 & 0.081 & $0.044^{*}$ \\
\cline { 2 - 7 } & $\mathrm{F}$ & 2.406 & 2.270 & 0.177 & 2.293 & 2.769 \\
\hline \multirow{3}{*}{ Gender } & Sig. & 0.510 & $0.008^{*}$ & 0.970 & 0.959 & 0.181 \\
\cline { 2 - 7 } & $\mathrm{F}$ & 0.437 & 7.195 & 0.001 & 0.003 & 1.806 \\
\hline \multirow{2}{*}{ Rank } & Sig. & 0.944 & 0.148 & $0.001^{*}$ & 0.768 & $0.001^{*}$ \\
\cline { 2 - 7 } & $\mathrm{F}$ & 0.127 & 1.809 & 5.761 & 0.379 & 5.692 \\
\hline \multirow{2}{*}{ Qualification } & Sig. & 0.142 & 0.396 & 0.304 & 0.709 & 0.542 \\
\cline { 2 - 7 } & $\mathrm{F}$ & 1.561 & 1.059 & 1.199 & 0.680 & 0.872 \\
\hline & Sig. & 0.337 & 0.784 & $0.016^{*}$ & 0.150 & $0.002^{*}$ \\
\cline { 2 - 7 } & $\mathrm{F}$ & 1.134 & 0.358 & 3.580 & 1.802 & 5.378 \\
\hline
\end{tabular}




\begin{tabular}{|l|c|c|c|c|c|c|}
\hline \multirow{2}{*}{ Career Level } & Sig. & 0.322 & 0.424 & 0.994 & 0.065 & 0.119 \\
\cline { 2 - 7 } & $\mathrm{F}$ & 1.181 & 0.973 & 0.057 & 2.269 & 1.873 \\
\cline { 2 - 7 } & Sig. & 0.788 & 0.842 & 0.258 & 0.082 & 0.440 \\
\cline { 2 - 7 } & $\mathrm{F}$ & 0.352 & 0.278 & 1.359 & 2.282 & 0.905 \\
\cline { 2 - 7 } $\begin{array}{l}\text { Courses of Crisis } \\
\text { Management }\end{array}$ & $\mathrm{Sig}$. & $0.003^{*}$ & 0.182 & 0.515 & 0.238 & 0.187 \\
\hline $\begin{array}{l}\text { Courses in } \\
\text { Information } \\
\text { Technology }\end{array}$ & $\mathrm{F}$ & 4.869 & 1.646 & 0.765 & 1.426 & 1.623 \\
\cline { 2 - 7 } $\begin{array}{l}\text { Forums Crisis } \\
\text { Management }\end{array}$ & $\mathrm{F}$ & 0.810 & 0.391 & 0.831 & 0.382 & $0.031^{*}$ \\
\hline $\begin{array}{l}\text { Forums Information } \\
\text { Technology }\end{array}$ & $\mathrm{Sig}$. & 0.136 & 0.090 & $0.014^{*}$ & 0.626 & 0.126 \\
\cline { 2 - 7 } & $\mathrm{F}$ & 2.245 & 2.913 & 6.195 & 0.239 & 2.370 \\
\cline { 2 - 7 } & $\mathrm{F}$ & $6.002^{*}$ & 0.251 & 0.333 & $0.043^{*}$ & 0.190 \\
\hline
\end{tabular}

$* \mathrm{P}<.05$.

Analysis of the demographic profile indicates that there is no statistically significant association between demographic data (i.e. rank, career level, experience, etc.) and the outcome of the survey. This analysis also confirms that the nature of work within various security institutions is the same, regardless of demographic factors.

\section{Discussion}

Communication technology is considered an essential tool in the effective management of security crises; however, interpersonal communication must also play a fundamental role. This basic consensus regarding communication development has been interpreted and applied in different ways throughout the past century. Differing perspectives regarding effective communication have emerged at the theoretical and research levels, as well as the planning and policy making levels [19]. This study outlined the findings on the effectiveness of communications in security sector disaster and crisis management in Yemen. A case study approach was combined with a questionnaire to determine common means and methods of communication, and to obtain a set of propositions from our observations and quantitative data analyses. Statistical analysis and our observations indicated that almost all participants surveyed agree that communications are important to the success of their own institution.

However, it is evident that most of the respondents are mainly concerned with obtaining information from others, rather than providing others with the information at their disposal. The actual level of communication among different security institutions is unsatisfactory. This case study and survey allows us to identify some factors that can hinder or facilitate efficient and effective inter-institutional communications at various levels. At the national level, authorities and laws can motivate inter-institutional coordination, communication, and information sharing by implementing institutional mechanisms related to guidelines and organizational policies. Detailed information regarding the data collected is explained below:

1. The average effectiveness of dealing with crises, in terms of the type of communications, is between (3.35-3.40). The statement (Communication mode prevails from the senior leadership to executive levels during crisis management) is ranked first in terms of the importance of communication types used in security crisis management. This result significantly differs from the findings of the study by Al Hamidi[7] which his study took place in Kingdom of Saudi Arabia, in which "formal contacts are preferred to clarify operational side" is the most common answer. This indicates the security sector is confronting challenges and frequent disasters and crises, which leads employees to transcend formal communication, in order to maintain speed of response. The study also supports informal contact with leadership during the crisis, consistent with the results 
from (Al Madi 1996. and Al Hamidi 2010)[18],[7], in which the use of informal channels of communication is encouraged to complete the missing links in business administration. Findings also show statistically significant differences in all values of the Chi-square, which are found to have a significant and negative relationship in support of hypothesis H1.

2. The mean values of all items regarding the methods of communication range between (4.11-2.60) and are considered statistically significant at (0.05) or less. As a result, the research findings showed that communication methods, such as "Oral communication through devices" is ranked first, and "Reliance on oral, direct personal contact" is ranked second. This refers to the speed of communication, considering that the audio devices easy to carry and movement. Oral communication helps minimize confusion and generates a positive connection between speakers. Additionally, direct personal contact fosters positive relationships. Listening extends far beyond hearing and understanding words.

3.The findings of this research, regarding the means of communication in security institutions, showed consistency with the studies of (Jarghoun A 2013 and Al Hamidi 2010) [17],[7] and revealed that common means of communication include mobile phones, fax, handheld devices, wireless communications, and written letters and telegrams. These findings suggest some similarities between some Arab and Yemeni security sectors. In addition, Adams shows that use of mobile phones is the most effective way to communicate to security agencies during a crisis [20]. Also, the use of satellite imagery, radio, close circuit television, surveillance cameras, television, and social network analysis are very effective ways to communicate during a crisis, while data mining and fax machines are the least effective. Therefore, dependence on a computerized information center and modern means of ICT is inevitable. This leads to improving external and internal interactions and communications between security personnel, the public, and government, as well as the ability to use databases to store and retrieve data.

4. This study also identifies factors that hinder effective communication during crisis management. Although the research shows that larger organizations are typically more prepared than smaller organizations [21],[22], it is not shown that there is a significant relationship between factors that hinder effective communication and perceived effectiveness of crisis management. Means for evaluation of factors that hinder effective communication were high, ranging from $\mathrm{M}=3.58$ for "Lack of requirements" to $\mathrm{M}=$ 4.24 for "Contrariety in competencies of crisis," which accounts for the lack of significant difference across factors that hinder communication.

5. The results showed that there was a high and comparable level of all the terms of proposals of communications activation during a crisis or disaster, Means for evaluation of proposals were high, ranging from 3.71-4.68, when staffs were asked to evaluate their management of the most recent crisis event. This reflects the size of the obstacles confronting security agencies, which were discussed in the previous item.

Statistical results of this study showed that legislative authority and senior government officials in the security sector should enforce effective security policies - mainly proactive strategies for overcoming a crisis - by taking advantage of modern technology and activating communication and coordination, in order to promptly and effectively manage crises.

At times, there are joint operations spanning several sectors and sharing important information to achieve a common goal. According to Avery and Seppanen, an effective information system enables all parties involved to share information in real time, despite their geographic distribution. In order to effectively communicate, experts need to have information sharing systems in place [23],[24]. 
Second hypothesis (H2): The significance values (.Sig) in the results of the "One Way ANOVA" test exceed the 0.05 level in most demographic profiles, which indicates homogeneity among the study sample responses and similarity in working conditions (i.e. regulations, procedures, sector, laws). There is a slight difference in the institutions' proposed solutions; this refers to the difference in the possibilities and awareness level in some institutions. The results showed that there were statistically significant differences at $\mathrm{p}<0.05$ regarding the statement "communication means and proposals to activate communications" depending on the age variable, where the value of $((\mathrm{F}=5.761,5.692)$ at the level of significance $(\operatorname{Sig}=.001 *, .001 *)$. To find out the reasons for these differences, researchers used the LSD test. The results indicate that there are differences between those aged thirty or younger, and those age 31-40 and 41-50 years. These results are attributed most to level of qualification and higher level of awareness of the means of communication and proposals to activate communications. The findings showed that there are not statistically significant differences at the level less than 0.05 in the responses among the study sample regarding their opinions on (Connection types) at the level of sig $(.003 *)$ and $(\mathrm{F}=4.869)$, according to differences in a variable of courses of crisis management. In addition, the findings showed that there are statistically significant differences in responses among the study sample regarding their opinions on (proposals activating communication) at the level of sig $(0.031)$ and $(\mathrm{F}=3.046)$ in the context of the variable of courses in information technology. These results are consistent with $\mathrm{Al}$ Hamidi [7] study in that there are statistically significant differences and disagreements among Al-Mutairi [25] studies, in which there are no statistically significant differences in the trends of respondents (Demographic Profile).

\section{Conclusion and Recommendations}

Security institutions in Yemen seem to have lack of communication adequately during crises, which can lead to serious consequences. The Yemeni security sector has experience in traditional dealings with crises and disasters; however, the country needs to develop more modern communication and information technologies in order to overcome obstacles in the coming years.

The results of this study indicate the need for the establishment of a command center (General administration), which has branches in all major cities. In addition, there is a significant lack of scientific training, rehabilitation, and provision of modern means for dealing with crises and disasters. Indeed, a detailed plan to confront crises is important, as well as establishing monitoring systems and practices to detect early warning signals of any foreseeable crisis. Moreover, it is essential to establish and train a crisis management team or select an external crisis management firm with a proven track record in the same field, and involve as many stakeholders as possible in all planning and response phases.

\section{Acknowledgments}

The authors would like to thank Faculty of business administration Hohai University for help. In addition thank ministry of Higher Education and Scientific Research in Yemen for support.

\section{References}

[1] J. N. Rosenau, "Turbulence in world politics: A theory of change and continuity", Princeton University Press, (1990)

[2] A.Lesebciuc and N. Daniela, "Role of communication in crisis management", Defense Resources Management in the 21st Century, (2008).

[3] W.T.Coombs, "Crisis management and communications. Institute for public relations", vol. 4, no. 5, (2007), p. 6.

[4] A.K.Al Kubaisi, "control of fraudulent crimes: Strengthening cooperation between government agencies and private universities - ways to dealing and coordination between government and private 
sectors: why and how, in Graduate Studies", Naif Arab University of Security Sciences: Riyadh, (2006) p. 74.

[5] J.Servaes, Approaches to development communication. Paris: Unesco. (2003).

[6] H.F.Durrant-Whyte, "Integration, coordination and control of multi-sensor robot systems", Springer Science \& Business Media, vol. 36.(2012).

[7] S.H.A.Al Hamidi, "The effectiveness of communication in the security crisis management in Interior Ministry Sectors in Administrative Sciences", Naif Arab University for Security Sciences: Riyadh (2010).

[8] M.A.G.H.Hilal, "Crisis management skills: the crisis between prevention and control. The development center of performance and development", Cairo: vol. 3, (2004).

[9] W.T.Coombs, "Ongoing crisis communication: Planning, managing, and responding", Sage Publications.

[10] L.Barton, "Crisis in organizations II", 2000: South-Western College Publishing, (2014).

[11] F.A. Shaalan, "Crisis management: foundations - phases - the mechanisms", University of Naif Arab Academy for Security Sciences, Riyadh, (2005).

[12] A.S.Brown, \& P. M. P.IPMA-C, "Strategic project management. in PMI 2006 North America Congress", WA, USA: PMI 2006 North America Congress, (2006).

[13] D.R.Griffin, and R. foreward Falk, "The New Pearl Harbor", Olive Branch Press SanFrancisco,(2004).

[14] K.Hallahan, "Defining strategic communication", International journal of strategic communication, vol. 1, (2007), p. 3-35.

[15] A. Pinsonneault, and K. Kraemer, "Survey research methodology in management information systems: an assessment", Journal of management information systems, vol. 10, no. 2, (1993), p. 75-105.

[16] J.F. Hair, et al, "Essentials of business research methods. vol. second edition, London England: ME Sharpe. Inc., (2015).

[17] A, A.Jarghoun \& M M.Al-Farra, Role of information technology in the coordination between the security forces Of Palestinian "Case Study: Interior Minister of the Palestinian, Islamic University: Gaza Strip, Palestinian (2013).

[18] A. S .Al madi, obstacles to contact the administrative and its impact on job performance: Analytic Study applied to middle and executive management levels, in Administration Sciences., Naiff Arab University for Security Sciences: Riyadh (1996).

[19] J.Servaes, and P. Malikhao, Development communication approaches in an international perspective. Communication for development and social change, (2008) p. 158

[20] O.Adams, "The Role of Information Technology in National Security:"A Case Study of Nigeria". Global Journal of Computer Science and Technology, 16, no. 3, (2016).

[21] W.Johansen, H.K. Aggerholm, and F. Frandsen, Entering new territory: A study of internal crisis management and crisis communication in organizations. Public Relations Review, vol. 38, no. 2, (2012), p. 270-279.

[22] D.W.Guth, "Organizational crisis experience and public relations roles", Public Relations Review, vol. 21, no. 2, (1995), p. 123-136.

[23] E.J.Avery, M. Graham, and S. Park, "Planning Makes (Closer to) Perfect: Exploring United States' Local Government Officials' Evaluations of Crisis Management", Journal of Contingencies and Crisis Management, vol. 24, no. 2, (2016) p. 73-81.

[24] H.Seppänen, J. Mäkelä, ,P. Luokkala, \& K.Virrantaus, Developing shared situational awareness for emergency management. Safety science, vol. 55, (2013), p. 1-9.

[25] S.M. Al-Mutairi, "Coordination among security agencies in seaports: its role in achieving security goals, in administration science", Naif Arab University for Security Sciences: Medina, (2011).

\section{Authors}

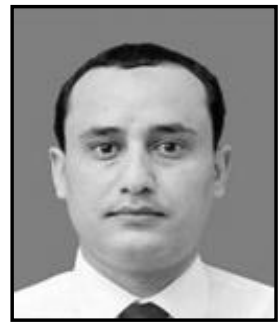

Fuad Mohsen Mohammed Nasr is a PhD Student At Hohai University In China. He Will Receive His PhD Degree From Faculty Of Business School. He Holds A Master In International Business From Southeast University, and Holds B.Sc In Accounting And Finance From Sana'a University. Besides, His Research And Publications Focus On Topics Such As Crisis Management, Management Information Systems (MIS), Technology Management, And Information Systems. 


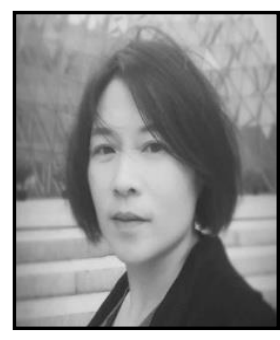

Tang Zheng is the voice present of Business School of Hohai University China. She has been working in Hohai University since 2004. She was a visiting scholar in Lehigh University and University of Calgary. Her research interest focuses on strategic management and transnational operation technique strategy and innovation management, and entrepreneurship and leadership. She has published books like "Strategic Management", History of Management Thoughts" and so on. 